\title{
Spatial distribution of bat richness in Mexico at different taxonomic levels: biogeographical and conservation implications
}

\author{
Kinberly Montserrat Barrios-Gómez ${ }^{1}$, Ricardo López-Wilchis ${ }^{2}{ }^{*}$, Jhoana Díaz-Larrea $^{3}$ \\ and Luis Manuel Guevara-Chumacero \\ Doctorado en Ciencias Biológicas y de la Salud, Universidad Autónoma Metropolitana. Av. San Rafael Atlixco 186, Col. Vicentina. \\ 09340, Ciudad de México. Email: s akurak@hotmail.com (KBG). \\ 2 Departamento de Biología, Universidad Autónoma Metropolitana-Iztapalapa. Av. San Rafael Atlixco 186, Col. Vicentina. 09340, \\ Ciudad de México. Email: rlw@xanum.uam.mx (RLW), Imgc@xanum.uam.mx (LMGC). \\ 3 Departamento de Hidrobiología, Universidad Autónoma Metropolitana-Iztapalapa. Av. San Rafael Atlixco 186, Col. Vicentina. \\ 09340, Ciudad de México. Email:jhoanadiazl@gmail.com (JDL). \\ * Corresponding author
}

Due to the potential of bats to travel long distances, the great diversity of habitats in which they are found, and their biological peculiarities, bats typically have been excluded in biogeographic analyses. However, like other mammals, bats show common distributional patterns strongly influenced by their biotic and abiotic interactions, aspects that have been poorly analyzed mainly due to technical and methodological limitations. Such occurrence data are limited to a subset of a species' range, the scale of occurrence records, characteristics of the life history (e.g., territory size, vagility) of the taxa being studied, and issues of environmental variable selection and, therefore, the modeling methods and the evaluation of them. In this work, the objectives were to: 1) Evaluate the spatial variation in bat richness in Mexico, both for the order as a whole and at the family taxonomic level. 2) Quantify overlapping species occurrences and corresponding richness values in order to statistically model and generate bat richness maps at different taxonomic levels. 3) Explore the relationship of bat richness with environmental factors and with the biogeographic regions proposed for Mexico. 4) Identify areas of interest with high richness. The information available on the Global Biodiversity Information Facility database for bat species with distribution in Mexico was downloaded, and clearly erroneous records deleted. Using the Kriging Ordinary utility (KO), inside the QGIS software, a geostatistical analysis interpolation data was used to determine patterns of richness. The relationship of bat richness to climate, vegetation, and the biotic provinces proposed for Mexico was also explored. Spatial variation in richness was evaluated at the taxonomic levels of order and family. Based on this determination, areas of interest were identified for their high richness. When considering all species of bats the highest diversity is in the central part of the West, the Northeast zone and on both sides of the Isthmus of Tehuantepec. However, there are differences present at the family level. Deciduous tropical forest vegetation type presents high bat richness, followed by pine-oak forest and evergreen tropical forest. Temperate sub-humid, warm sub-humid and warm-humid climate types correspond to the highest bat richness of both order and family. Collection localities are not uniformly distributed over the country, most of them being concentrated in the west, east and south of the country, while there are very few records in the north and central plateau, and this is reflected in the richness concentration per cell (values from 0 to 52 species per cell). Protection of the four areas with an overall high concentration of bat richness detected in this analysis should be a priority during the development of conservation strategies.

Debido a su amplia capacidad de desplazamiento, la gran diversidad de hábitats en los que se les encuentra y a sus peculiaridades biológicas, los murciélagos han sido excluidos o marginados en muchos análisis biogeográficos. No obstante, se puede esperar que presenten patrones comunes que caractericen su distribución y que exista una regionalización fuertemente influenciada por sus interacciones bióticas y abióticas, aspectos que han sido poco abordados, principalmente por limitaciones técnicas y metodológicas. En este trabajo los objetivos fueron: 1) Evaluar la variación espacial de la riqueza de murciélagos en México, tanto a nivel general como a nivel de familias. 2) cuantificar las ocurrencias de especies superpuestas y los valores de riqueza correspondientes con el fin de modelar estadísticamente y generar mapas de riqueza de murciélagos a diferentes niveles taxonómicos. 3) Explorar la relación de la riqueza de murciélagos con diferentes factores ambientales y con las regiones biogeográficas propuestas para México. 4) Identificar áreas de interés con alta diversidad. La información disponible en la base de datos Global Biodiversity Information Facility para las especies de murciélagos con distribución en México fue depurada, y mediante la utilería de "kriging ordinario (KO)", del programa QGIS, se sometió a un análisis geoestadístico de interpolación de datos para determinar sus patrones de riqueza y la generación de mapas que resaltan este aspecto. La variación espacial de riqueza se evaluó en los niveles taxonómicos de orden y familia. Las áreas con mayor riqueza para la totalidad de especies de murciélagos se localizan en la parte central del Occidente, la zona Nororiental y a ambos lados del Istmo de Tehuantepec. Sin embargo, hay diferencias a nivel de familia. El tipo de vegetación de bosque tropical caducifolio presenta una gran riqueza de murciélagos, seguido del bosque de pino y encino y el bosque tropical perennifolio. Los climas templado subhúmedo, cálido subhúmedo y cálido húmedo corresponden a la mayor riqueza de murciélagos. Los registros de las localidades colectadas no se encuentran distribuidas de manera uniforme en el país, la mayoría de ellas están concentradas en el oeste, este y sur del país, mientras que hay muy pocos registros en la meseta norte y central, sesgo que se refleja en la concentración de riqueza por celda (valores de 0 a 52 especies por celda). La protección de las cuatro áreas con una alta concentración general de la riqueza de murciélagos detectada en este análisis debe ser una prioridad durante el desarrollo de las estrategias de conservación.

Keywords: biogeographic regions; environmental factors; geostatistical method; kriging; Mexican bats; richness maps.

๑) 2019 Asociación Mexicana de Mastozoología, www.mastozoologiamexicana.org 


\section{Introduction}

The majority of studies on bat richness have focused on the roles of spatial scales and sampling methods (Bergallo et al. 2003; Meyer et al. 2011; Skalak et al. 2012) as well as the relationships between richness and different environmental parameters (McCain 2007; Tello and Stevens 2010; López-González et al. 2012; Schoeman et al. 2013; LópezGonzález et al. 2015). Other studies have evaluated the effects of habitat deterioration on richness at the local, regional or global level (Estrada et al. 1993; Estrada and Coates-Estrada 2001; Mehr et al. 2011; Frey-Ehrenbold et al. 2013). In recent years, the study of biological richness has acquired greater relevance as a means for evaluating the impacts of global environmental changes and human activities, wherein more robust and reliable estimates using new approaches are required in order to improve analyses (Henry et al. 2010; Bellamy et al. 2013). Also, in the last two decades greater attention has been placed on the adaptive responses of bats to habitat heterogeneity in addition to the effects of habitat modification on functional and phylogenetic diversity (Soriano 2000; Stevens et al. 2003; Roncancio and Estevés 2007; Cisneros et al. 2014; Melo et al. 2014; Aguirre et al. 2016; Scheiner et al. 2016).

The systematics and the anatomy of bats have been widely studied as well as different aspects of their behavior, physiology and ecology (Altringham 1997; Crichton and Krutzsch 2000; Neuweiler 2000; Kunz and Fenton 2003; Simmons 2005; Fenton and Simmons 2015). Compared with other mammals, bats are small in size and have great longevity, a relatively long gestation period and a low reproductive rate (Brunet-Rossini and Austad 2004). Bats occupy a wide variety of habitats and roost in both natural and manmade structures and are adapted to living in specialized or somewhat uncommon environments and are highly responsive to environmental variables. Finally, bats can perform long-distance movements of various kilometers on a daily basis and are capable of extensive migrations (Findley 1993). Notwithstanding the biological distinctiveness of bats and their great capacity of displacement, it is expected that bats present common patterns in their distributions that are regionalized and influenced by biotic and abiotic interactions.

Bat distribution patterns have been little studied, mainly due to logistical and methodological limitations. One of the most recurrent problems was the limited occurrence records to characterize the species' range. Others more complex, were to scale the occurrence data to the characteristics of the life history (e. g., vagility), the issues of environmental variable selection and the lack of models to analyze them jointly (Phillips et al. 2006; Rondinini et al. 2006; Segura-Trujillo and Navarro- Pérez 2010).

Mexico is considered a megadiverse country due to the large number of plant and animal species that inhabit its territory (Arita 1997; Ceballos et al., 1998; Sarukhán et al. 2014). This diversity results from the geographical position, geological history and the rugged topography of Mexico, which create a diverse mosaic of environmental and microenvironmental conditions. In Mexico, 512 species of terrestrial mammals have been recorded (Álvarez-Castañeda et al. 2017), and their general distribution at the species level has been largely mapped since the last half of the past century (Hall and Kelson 1959), enabling richness patterns to be studied. Such information has also been used to propose various biogeographical regions for the country, the majority of which are predominantly based on the distributions of terrestrial mammals (Ramírez-Pulido and Castro-Campillo 1990, 1993; Arita 1993, 1997; Arriaga et al. 1997; Escalante et al. 2002; Escalante et al. 2003; Escalante et al. 2007). Unquestionably, these studies have contributed towards increasing knowledge of the country's biogeography but have often excluded or marginalized bats based on their biological differences, the size of their distribution areas and their capacity for widespread movement.

Biogeographical works carried out specifically on Mexican bats are scarce: Arita and Ortega (1998) have proposed that the richness and diversity of bats responds to a latitudinal gradient; Wang et al. (2003) made a species richness prediction map for the chiroptera in the state of Michoacán using temperature, precipitation, soil and vegetation environmental data. López-González et al. (2012) proposed that the distribution of bats along environmental gradients is determined by characteristics of the species group present in a site and not for the study areas defined arbitrarily which confine them. Grimshaw and Higgins (2017) analyzed the correlation of the phylogenetic structure in Mexican bat communities with environmental factors as temperature, precipitation, latitude, and longitude.

In this context, the distribution of bat richness at taxonomic levels not previously evaluated is important for understanding how bats relate to the biogeographical regions proposed for Mexico. In addition, more in-depth analyses are needed on the influence of important environmental variables (latitude, climate and vegetation) on the structuring of bat richness patterns. Bats are particularly sensitive to habitat destruction and to environmental changes, although it also has been reported that the response of bats to change in land use is varied and depends on the taxonomic group (García-Morales et al. 2013). A precise map of their species richness patterns will enable the variation in such patterns to be better understood and aid in the design of effective regional conservation schemes.

The development of Geographic Information Systems (GIS) along with geostatistical methods and the wide availability of species occurrence records in online databases enable the in-depth analysis of spatial correlations among variables using diverse functions that estimate or predict the values and the distribution of a property across space and time. The Kriging method facilitates the interpolation of different variables, allows spatial estimation for prediction of values in areas where data is not available, based on a limited number of points obtained from a sample, useful for the analysis of species patterns distributions (Fortin et 
al. 2005; ESRI 2006; Tittensor et al. 2010; Hortal and Lobo 2011; Henríquez et al. 2013; Tapia-Silva et al. 2015). Kriging appears to be appropriate for the creation of thematic maps for visualizing zones of greatest species richness under the combined effect of some variables.

The present study had the following objectives: 1) evaluate the spatial variation in bat richness in Mexico, both overall and at the family level. 2) Quantify overlapping species occurrences and corresponding richness values in order to statistically model and generate bat richness maps at different taxonomical levels. 3) Explore the relationship of bat richness with different environmental factors and with the complex biogeographic regions proposed for Mexico. 4) Identify areas of interest with high diversity.

\section{Material and Methods}

Databases. Locality records for bats in Mexico were obtained from the online database of the Global Biodiversity Information Facility (GBIF; http://www.gbif.org accessed in January 2016). Only georeferenced distribution records supported with specimens deposited in scientific collections, either national or foreign, were considered. The data were reviewed with respect to their geographical distribution and nomenclatural status according to Medellín et al. (2008) and Álvarez-Castañeda et al. (2015). Island records were eliminated as well as reports outside the known geographic distribution of species. Species sampled in less than five localities were not included under the assumption that such records were not sufficient for representing the overall distribution of a species. The edited data set was exported to a database constructed in MS Excel 2011. The database was composed of 6,979 presence records corresponding to 97 species belonging to eight families of Chiroptera distributed throughout Mexico (Table 1), which represents 70.3 $\%$ of the 138 species registered for the country (ÁlvarezCastañeda et al. 2017). The 39 species omitted from the analysis is due to that for some of them there are no records in GBIF, others have fewer than five records and also the families represented by a single species cannot be considered in the geostatistical method used.

Study area. The area of continental Mexico (32 $43^{\prime} 06^{\prime \prime}$ $\mathrm{N},-114^{\circ} 45^{\prime} \mathrm{W} ; 14^{\circ} 32^{\prime} 27^{\prime \prime} \mathrm{N},-92^{\circ} 13^{\prime} 0^{\prime \prime} \mathrm{W}$ ), which covers an area of $1,964,375 \mathrm{~km}^{2}$, was considered in the analysis. The Comisión Nacional para el Conocimiento y Uso de la Biodiversidad (CONABIO), based on Rzedowski (1990), has proposed nine main vegetation types for Mexico, of which eight were used in our analysis, because the aquatic and sub-aquatic vegetation type was excluded. Also, we employed the 13 main climatic types recognized by García (1998). For the biogeographic regionalization we used the map of Morrone (2005) which depicted 14 biotic provinces according to their ecology and ecological history, and supported by the overlapping distributions of different groups of species.

Determination of richness patterns. A map was created for Mexico (INEGI, scale 1:1,000,000) using the WGS 84

Table 1. Families of Mexican bats considered in this study with their number of species and localities. The data were obtained from an analysis of the information deposited in the online database Global Biodiversity Information Facility (GBIF http:// www.gbif.org/ - Accessed January 2016)

\begin{tabular}{|c|c|c|c|}
\hline \multicolumn{4}{|c|}{ Emballonuridae: Species 7 Localities 373} \\
\hline Balantiopteryx io & 25 & Peropteryx macrotis & 30 \\
\hline Balantiopteryx plicata & 201 & Rhynchonycteris naso & 17 \\
\hline Diclidurus albus & 9 & Saccopteryx bilineata & 84 \\
\hline Peropteryx kappleri & 7 & & \\
\hline \multicolumn{4}{|c|}{ Molossidae: Species 12 Localities 27} \\
\hline Eumops ferox & 11 & Nyctinomops aurispinosus & 14 \\
\hline Eumops perotis & 6 & Nyctinomops femorosaccus & 36 \\
\hline Eumops underwoodi & 13 & Nyctinomops laticaudatus & 27 \\
\hline Molossus molossus & 24 & Nyctinomops macrotis & 16 \\
\hline Molossus rufus & 25 & Promops centralis & 7 \\
\hline Molossus sinaloae & 20 & Tadarida brasiliensis & 226 \\
\hline \multicolumn{4}{|c|}{ Mormoopidae: Species 4 Localities 778} \\
\hline Mormoops megalophylla & 330 & Pteronotus parnellii & 232 \\
\hline Pteronotus davyi & 139 & Pteronotus personatus & 77 \\
\hline \multicolumn{4}{|c|}{ Natalidae: Species 1 Localities 172} \\
\hline Natalus mexicanus & 172 & & \\
\hline \multicolumn{4}{|c|}{ Noctilionidae: Species 1 Localities 41} \\
\hline Noctilio leporinus & 41 & & \\
\hline \multicolumn{4}{|c|}{ Phyllostomidae: Species 38 Localities 3960} \\
\hline Dermanura azteca & 34 & Glossophaga leachii & 69 \\
\hline Dermanura phaeotis & 189 & Glossophaga morenoi & 18 \\
\hline Dermanura tolteca & 176 & Glossophaga soricina & 543 \\
\hline Anoura geoffroyi & 100 & Glyphonycteris sylvestris & 9 \\
\hline Artibeus hirsutus & 61 & Hylonycteris underwoodi & 15 \\
\hline Artibeus jamaicensis & 442 & Leptonycteris nivalis & 51 \\
\hline Artibeus lituratus & 347 & Leptonycteris yerbabuenae & 110 \\
\hline Chrotopterus auritus & 11 & Macrotus californicus & 73 \\
\hline Choeroniscus godmani & 14 & Mimon cozumelae & 16 \\
\hline Choeronycteris mexicana & 114 & Musonycteris harrisoni & 13 \\
\hline Carollia perspicillata & 90 & Micronycteris microtis & 32 \\
\hline Carollia subrufa & 90 & Macrotus waterhousii & 73 \\
\hline Chiroderma salvini & 45 & Phyllostomus discolor & 32 \\
\hline Chiroderma villosum & 32 & Platyrrhinus helleri & 24 \\
\hline Centurio senex & 59 & Sturnira parvidens & 333 \\
\hline Diphylla ecaudata & 35 & Sturnira hondurensis & 123 \\
\hline Desmodus rotundus & 420 & Trachops cirrhosus & 24 \\
\hline Enchisthenes hartii & 13 & Uroderma bilobatum & 47 \\
\hline Glossophaga commissarisi & 76 & Vampyrodes caraccioli & 7 \\
\hline \multicolumn{4}{|c|}{ Thyropteridae: Species 1 Localities 5} \\
\hline Thyroptera tricolor & 5 & & \\
\hline \multicolumn{4}{|c|}{ Vespertilionidae: Species 33 Localities 1623} \\
\hline Antrozous pallidus & 86 & Myotis keaysi & 30 \\
\hline Corynorhinus mexicanus & 17 & Myotis nigricans & 39 \\
\hline Corynorhinus townsendii & 10 & Myotis peninsularis & 8 \\
\hline Eptesicus furinalis & 44 & Myotis planiceps & 6 \\
\hline Eptesicus fuscus & 186 & Myotis thysanodes & 32 \\
\hline Idionycteris phyllotis & 7 & Myotis velifer & 191 \\
\hline Lasiurus blossevillii & 22 & Myotis vivesi & 42 \\
\hline Lasiurus borealis & 50 & Myotis volans & 29 \\
\hline Lasiurus cinereus & 57 & Myotis yumanensis & 60 \\
\hline Lasiurus ega & 75 & Nycticeius humeralis & 20 \\
\hline Lasiurus intermedius & 43 & Pipistrellus hesperus & 170 \\
\hline Lasiurus xanthinus & 14 & Pipistrellus subflavus & 9 \\
\hline Myotis auriculus & 21 & Rhogeessa aeneus & 5 \\
\hline Myotis californicus & 127 & Rhogeessa bickhami & 5 \\
\hline Myotis elegans & 11 & Rhogeessa parvula & 78 \\
\hline Myotis evotis & 10 & Rhogeessa tumida & 59 \\
\hline Myotis fortidens & 60 & & \\
\hline
\end{tabular}


(World Geodetic System 84) datum and was divided into quadrants of $1^{\circ} \times 1^{\circ}$, resulting in 253 cells with their respective identification according to Hansen (1997). Bat records were assigned to a cell based on their georeferenced coordinates, and this was also performed independently for each family of bats, regardless of the number of specimens or the date of collection. These records were overlapped with the following data layers: vegetation types, scale1:250,000; climate types, scale1:1,000,000; and biotic provinces, scale1:4,000,000. The layer of biotic provinces was built by digitizing the map of Morrone (2005); the vegetation and climate layers were obtained from the CONABIO portal (http://www. conabio.gob.mx/informacion/gis/).

Geostatistical interpolations of the spatial data were performed with Surfer 11 (Golden Software, Golden, CO, USA) and exported into QGIS software v. 2.12.2 (www.qgis.org) to obtain bat richness values and to generate the corresponding maps for the 96 species and independently for members of the families Emballonuridae, Molossidae, Mormoopidae, Phyllostomidae and Vespertilionidae. The families Natalidae, Noctilionidae and Thyropteridae were included only in the overall richness assessment because each is represented by only one species in Mexico.
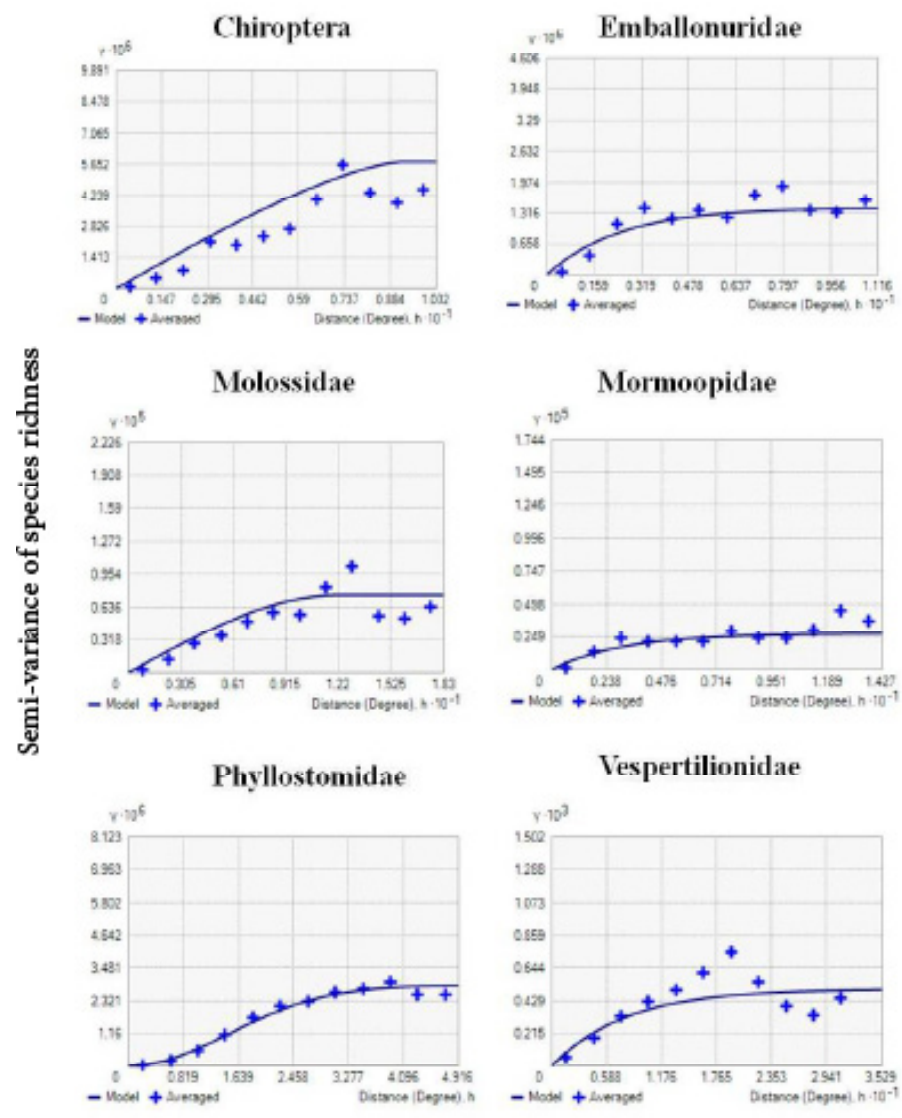

Distance (degrees)

Figure 1. Cross-validation for selecting each semivariogram model generated by ordinary kriging. A circular model was selected for the Chiroptera order (error $=0.000$ ), spherical for the family Mormoopidae (error $=0.037$ ) and exponential for the families Emballonuridae, Molossidae, Phyllostomidae and Vespertilionidae (error $=0.034 ; 0.038$; 100.000 and 0.006 , respectively).
To determine the best model to apply for each family and for the group as a whole, a cross-validation analysis was performed for each semivariogram model generated by the OK tool. Because the best model is that whose error measure is closest to zero (Díaz 2002), the selected model for the Order Chiroptera (all species together) was circular (error $=0.0001$ ), while a spherical model was selected for the family Mormoopidae (error $=0.037$ ) and an exponential model for the families Emballonuridae, Molossidae, Phyllostomidae and Vespertilionidae (error $=0.034 ; 0.038 ; 0.000$ and 0.006 respectively; Figure 1).

We selected the OK method because it is mainly based on the geographical distance of points to those in neighboring cells, more than the size of cells, which enables geographical units that are not necessarily adjacent or that are spaced at regular intervals to be compared. The spatial structure of the data is usually described in an experimental variogram, which is basically a graph of the semivariance between observation pairs (in this case cells) with respect to distance in a geographic space; descriptions of the requirements for the use of OK can be found in Díaz (2002), Hengl (2009) and Cruz-Cárdenas et al. (2013). Based on the quantitative results, areas with a richness greater than $50 \%$ of species were considered to be high in richness, or 'rich', while areas with less than $10 \%$ of species were considered low in richness, or 'poor'.

\section{Results}

The distribution of presence records for the 97 species and eight families considered in the present study is shown in Figure 2. When all species of the order Chiroptera are considered the sample localities are dispersed throughout the country. However, at the family level, the distributions follow distinct patterns. Only the families Vespertilionidae and Molossidae are widely distributed. Meanwhile, records for the families Phyllostomidae, Mormoopidae and Natalidae are concentrated in the Pacific and Gulf of Mexico coastal plains, as well as in the central and southern portions, and are scarce or absent in the Central Mexican Plateau and in the northern-central areas of the country. Records for the families Emballonuridae, Noctilionidae and Thyropteridae were found along the Pacific Coastal Plains and in the south and south-eastern areas of the country, and notably missing in the central, northern and eastern areas of the territory.

Species richness per cell. Of the 253 cells into which Mexico was divided, 48 cells did not have bat records (19\%). These mostly are located in the north of the country. Thus, bat records were found in the remaining 205 cells. The cells had an average of 12 species per cell, with a minimum of one species and a maximum of 52 species (Table 2). Overall, $75 \%$ of cells presented richness values ranging from one to 17 species, $20 \%$ from 18 to 25 species and the remaining $5 \%$ from 36 to 51 species. The highest richness value was encountered in only one cell with 52 species, which was located in western Mexico on the border between the states of Colima and Jalisco. 

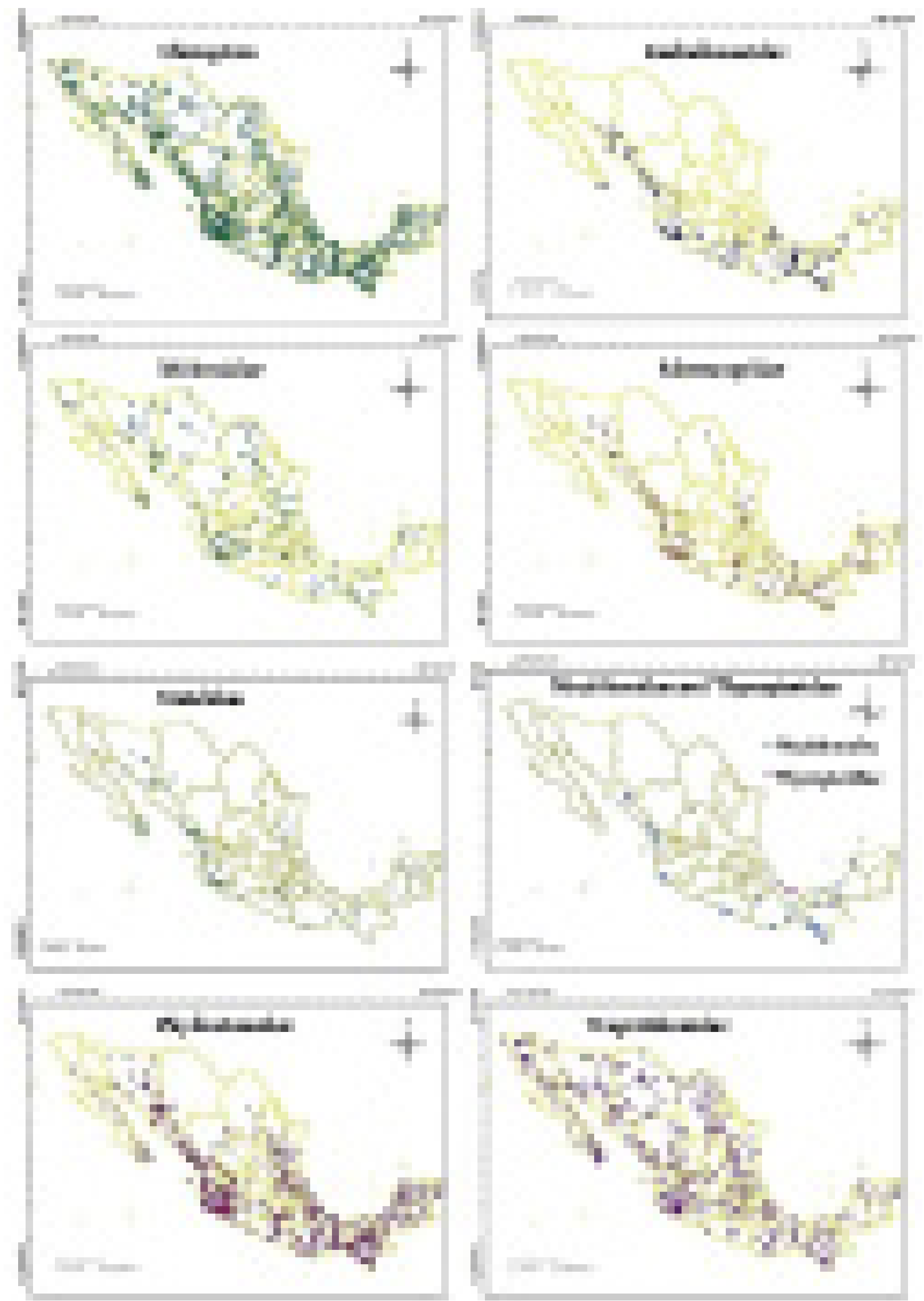

Figure 2. Maps showing the distribution of the 6,979 localities with presence records for the 97 species considered in this study and also their distribution at the family level. 
Table 2. Clades of Mexican bats with their species number, localities with bats records, number of cells with collecting records and average and maximum values of bat species richness recorded by cell.

\begin{tabular}{|c|c|c|c|c|c|}
\hline \multirow{2}{*}{$\begin{array}{c}\text { Taxonomic } \\
\text { group }\end{array}$} & \multirow[t]{2}{*}{ Species } & \multirow[t]{2}{*}{ Localities } & \multirow{2}{*}{$\begin{array}{l}\text { Cells with } \\
\text { records }\end{array}$} & \multicolumn{2}{|c|}{ Bat richness by cell } \\
\hline & & & & average & maximum \\
\hline Chiroptera & 97 & 6,979 & 205 & 12 & 52 \\
\hline Phyllostomidae & 38 & 3,960 & 149 & 8 & 25 \\
\hline Vespertilionidae & 33 & 1,623 & 184 & 3 & 18 \\
\hline Molossidae & 12 & 27 & 133 & 2 & 9 \\
\hline Emballonuridae & 7 & 373 & 64 & 2 & 6 \\
\hline Mormoopidae & 4 & 778 & 87 & 3 & 4 \\
\hline Natalidae & 1 & 172 & 56 & 1 & 1 \\
\hline Noctilionidae & 1 & 41 & 21 & 1 & 1 \\
\hline Thyropteridae & 1 & 5 & 3 & 1 & 1 \\
\hline
\end{tabular}

The number of cells with collecting records, and the average and maximum values of bat species richness recorded by cell for each bat family is show in Table 2 .

Analysis of the spatial distribution of species richness.

Order and families. Considering the 97 bat species together, the greatest richness was found in the Mexican Pacific Coast biotic province, the deciduous tropical forest vegetation type and the temperate sub-humid climate. For the family Emballonuridae the greatest richness was found in the Gulf of Mexico biotic province, the evergreen tropical forest vegetation type and the warm-humid climate. The family Molossidae presented the greatest richness in the Mexican Pacific Coast biotic province, the deciduous tropical forest vegetation type and the warm-humid climate. For each bat family the highest richness values in the biotic provinces, vegetation types as well as climates are presented in Tables 3 to 5 .

Biotic provinces. The results obtained for the interpolation of the distribution of the species richness and the biotic provinces are shown in Table 3 and Figure 3. The Mexican Pacific Coast and Gulf of Mexico provinces have the greatest richness of bats and the provinces of California and Tamaulipas contain the lowest numbers of species. All provinces contain vespertilionid bats, with generally high percentages of richness, wherein the Mexican Pacific Coast, Sierra Madre Oriental, Gulf of Mexico, and Transmexican Volcanic Belt provinces have high values. The majority of provinces have the presence of phyllostomids but the Mexican Pacific Coast and Gulf of Mexico provinces have notable richness value for this family, and only the California province was lacking in species for this family. With respect to mormoopids, 10 provinces can be highlighted for their high richness values, and the California province is the only one without mormoopids. The greatest molossid and emballonurid richness occurred in the Mexican Pacific Coast and Gulf of Mexico provinces. Bat records are absent in some portions of the following biotic provinces: Mexican Plateau ( 23 cells), Tamaulipas (9 cells), Sonora (8 cells), Baja California (4 cells), California ( 2 cells) and Yucatán Peninsula ( 2 cells).
Table 3. Percentages of richness for each bat taxonomic group in Mexico's different biotic provinces proposed by Morrone (2005): Baja California (BC), Balsas Basin (BB), California (CAL), Chiapas (CHI), Gulf of Mexico (GM), Mexican Pacific Coast (MPC), Mexican Plateau (MP), Sierra Madre del Sur (SMS), Sierra Madre Occidental (SMW), Sierra Madre Oriental (SME), Sonora (SON), Tamaulipas (TAM), Transmexican Volcanic Belt (TVB), Yucatán Peninsula (YP). Province/Group (P/G), Chiroptera $(\mathrm{CH})$, Emballonuridae (EM), Molossidae (ML), Mormoopidae (MR), Phyllostomidae (PH), and Vespertilionidae (VE).

\begin{tabular}{lcccccc}
\hline P/G & CH & EM & ML & MR & PH & VE \\
\hline MPC & 87 & 71 & 93 & 100 & 95 & 63 \\
GM & 74 & 86 & 43 & 100 & 87 & 53 \\
TBV & 59 & 14 & 57 & 75 & 59 & 53 \\
BB & 54 & 43 & 36 & 75 & 56 & 45 \\
SMS & 52 & 29 & 36 & 75 & 69 & 32 \\
SMW & 52 & 14 & 36 & 75 & 51 & 50 \\
SME & 51 & 0 & 50 & 75 & 44 & 55 \\
YP & 45 & 29 & 50 & 75 & 54 & 26 \\
CHI & 43 & 43 & 14 & 75 & 59 & 26 \\
SON & 43 & 14 & 43 & 75 & 33 & 45 \\
MP & 41 & 14 & 29 & 25 & 31 & 58 \\
BC & 33 & 14 & 29 & 25 & 15 & 47 \\
TAM & 14 & 0 & 7 & 25 & 13 & 13 \\
CAL & 7 & 0 & 0 & 0 & 0 & 18 \\
\hline
\end{tabular}

Vegetation types. Chiropteran richness is notable in the deciduous tropical forest, followed by pine and oak forest and evergreen tropical forest (Table 4). The vegetation type with poorest bat richness is grassland where only a few records for molossid, phyllostomid and vespertilionid bats are found. At the family level, Mormoopidae exhibits high richness values in six vegetation types: deciduous tropical forest, evergreen tropical forest, pine and oak forest, xerophile shrubland, tropical sub-deciduous and thorn forest. Phyllostomidae presents high richness values in pine and oak forest, evergreen tropical forest and deciduous tropical forest vegetation types. The maximum richness of Molossidae is in deciduous tropical forest, of Emballonuridae in evergreen tropical forest and of Vespertilionidae in xerophile shrubland. Bats were not present in 44 cells located in xerophile shrubland and in four cells of thorn forest.

Climate. The richness values for the Order Chiroptera are broadly distributed across diverse climate types (Table 5). The temperate sub-humid, warm sub-humid and warmhumid climate types presented the highest values for bat richness for both order and family levels. Emballonuridae presented high richness values in the warm-humid and warm sub-humid but in nine climate types their richness is zero. For the Molossidae and Phyllostomidae the climates warm sub-humid and temperate sub-humid have high richness values. Meanwhile, the richness values for the family Mormoopidae are high in nine climate types but were zero in another six climates, while the majority of climates have the presence of vespertilionids but not in high numbers. No bat records were found in 35 cells of semi-dry temperate climate, in six of semi-cold sub-humid, in five of very dry-very warm and in two of temperate-humid. For the climates cold, semi-warm humid, semi-dry semi-cold 

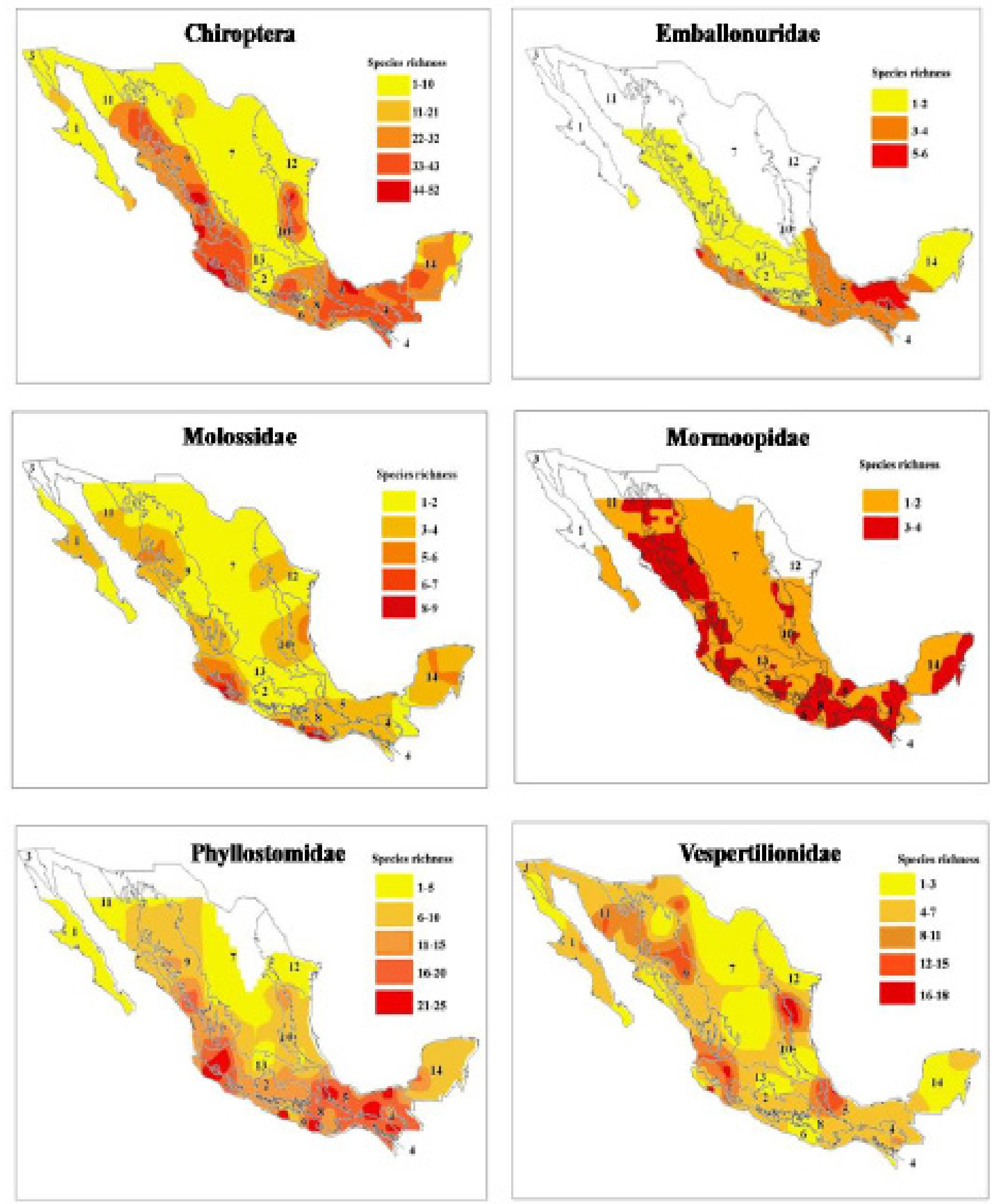

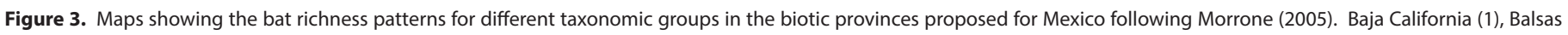

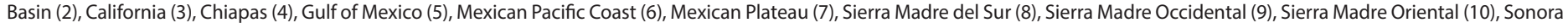
(11), Tamaulipas (12), Trasmexican Volcanic Belt (13), Yucatán Peninsula (14). 
Table 4. Percentages of richness for each bat taxonomic group in Mexico's different vegetation types proposed by Rzedowski (1990): Deciduous tropical forest (DTF), Evergreen tropical forest (ETF), Grassland (G), Pine-Oak forest (POF), Thorn forest (TF), Tropical sub-deciduous forest (TSDF), Xerophile shrubland (XS). Vegetation Type (VT), Chiroptera $(\mathrm{CH})$, Emballonuridae (EM), Molossidae (ML), Mormoopidae (MR), Phyllostomidae (PH), and Vespertilionidae (VE).

\begin{tabular}{ccccccc}
\hline VT & CH & EM & ML & MR & PH & VE \\
\hline DTF & 94 & 50 & 100 & 100 & 95 & 79 \\
POF & 85 & 38 & 64 & 75 & 90 & 79 \\
ETF & 82 & 88 & 50 & 100 & 92 & 63 \\
XS & 65 & 13 & 64 & 75 & 49 & 82 \\
TSDF & 48 & 50 & 50 & 75 & 59 & 21 \\
TF & 45 & 13 & 43 & 75 & 41 & 45 \\
G & 28 & 0 & 7 & 0 & 26 & 42 \\
\hline
\end{tabular}

and temperate-humid, an estimated richness value was not obtained.

\section{Modelling overlapping richness values (Maps)}

The maps resulting from the use of ordinary kriging do not show richness patterns that are concordant for the biotic provinces. There is not a biotic province in which there is a predominance or a clear concentration of the bat richness (Figure 3). Maps highlight different patterns of bat richness for each family, not concordant with biotic provinces. For the family Emballonuridae the richness is concentrated towards the coastal plains of the Pacific and Gulf of Mexico and generally in the southeast of the country. Bats of the family Molossidae are present throughout the country, but richness is especially concentered in five hotspots, three in the western regions of Sonora-Sinaloa, Jalisco-Colima and Oaxaca, one in the south of Chiapas and other in the Yucatan peninsula. In Mormoopidae richness is broadly distributed over the country, but decreases in the center, north and east. For Phyllostomidae richness is high over the country, more concentrated in the coastal plains of the Pacific and Gulf of Mexico and towards the southern portion but decreasing in the center and in the north. For the Vespertilionidae family, bat richness extends throughout the country, with several areas of high species richness located in the northwest and northeast, the central plateau, the isthmus of Tehuantepec and the Yucatan Peninsula (Figure 3).

\section{Discussion}

The collecting localities for bats are not uniformly distributed over the country, with most of them concentrated in the west, east and south, while there are a very few records in the north and central plateau. This reflects that there are fewer species in those parts of the country and also a bias in the efforts for collecting (Figure 2 Chiroptera map).

The use of GBIF has limitations due that there are only 97 species $(70.3 \%)$ of the 138 species registered for the country. The families Natalidae, Noctilionidae and Thyropteridae are poorly represented, have few records, and
Table 5. Percentages of richness for each bat taxonomic group in Mexico's climate types proposed by García (1998): Temperate sub-humid (Tsh), Warm subhumid (Wsh), Warm-humid (Wh), Semi-dry very warm (Sdvw), Semi-cold sub-humid (Scsh), Semi-calid subhumid (Scs), Warm-dry (Wd), Very dry semi-warm (Vdsw), Dry very warm (Dvw), Semi-dry temperate (Sdt), Semi-warm dry (Swd), Semi-dry warm (Sdw), Semi-dry semi-warm (Sdsw), Dry temperate (Dt), Very dry temperate (Vdt), Very dry-warm (Vdw), and Very dry-very warm (Vdvw). Climate/Group (C/G), Chiroptera $(\mathrm{CH})$, Emballonuridae (EM), Molossidae (ML), Mormoopidae (MR), Phyllostomidae $(\mathrm{PH})$, and Vespertilionidae (VE).

\begin{tabular}{ccccccc}
\hline C/G & CH & EM & ML & MR & PH & VE \\
\hline Tsh & 94 & 38 & 86 & 100 & 87 & 79 \\
Wsh & 69 & 75 & 100 & 100 & 100 & 63 \\
Wh & 34 & 88 & 50 & 75 & 85 & 45 \\
Sdvw & 34 & 38 & 21 & 75 & 36 & 16 \\
Scsh & 32 & 0 & 14 & 0 & 0 & 34 \\
Scs & 32 & 0 & 0 & 0 & 18 & 0 \\
Wd & 29 & 13 & 7 & 75 & 33 & 34 \\
Vdsw & 28 & 0 & 29 & 25 & 10 & 47 \\
Dvw & 25 & 0 & 0 & 50 & 18 & 8 \\
Sdt & 20 & 13 & 21 & 25 & 31 & 34 \\
Swd & 20 & 0 & 7 & 0 & 8 & 5 \\
Sdw & 16 & 0 & 29 & 50 & 13 & 39 \\
Sdsw & 13 & 0 & 14 & 50 & 10 & 37 \\
Dt & 8 & 0 & 14 & 0 & 5 & 42 \\
Vdt & 7 & 0 & 21 & 0 & 5 & 37 \\
Vdw & 3 & 13 & 36 & 75 & 18 & 39 \\
Vdvw & 0 & 13 & 7 & 0 & 0 & 3 \\
\hline
\end{tabular}

because they are monospecific families they cannot be included in the kriging analysis.

In our maps the comparisons among the richness patterns of bats demonstrate that the pattern of the order level can differ from the patterns of the constitutive families, as well as the richness patterns differing to a substantial extent among families.

Biogeographical approaches are used to examine the cause of the bat distribution patterns, as well as to trace the circumstances of the past that may have influenced to generate such patterns. Various environmental factors such as latitude, temperature, precipitation and topography have been proposed to explain the richness and diversity of bats in the New World. One of the most considered is the effect of the latitudinal gradient for which several studies have proposed that the number of species increases as the latitude decreases (Wilson 1974; Willig and Lyons 1998; McCoy and Connor 1980; Fa and Morales 1991; Kaufman 1995; Arita and Ortega 1998; Willig et al. 2003), even at the local level (Stevens and Willig 2002). But according to Patten (2004) annual precipitation, temperature, and topography are better predictors of species richness in Chiroptera than vegetative cover, which explained little variation, and latitude which explained an insignificant amount of residual variation in species richness. Also, Stevens (2004) stated that ecological and evolutionary differences among higher taxonomic units, those involving life-history traits, predispose taxa to exhibit different patterns of diversity along environmental gradients. 
Our results are more in agreement with Patten (2004) and Stevens (2004), but we only include a part of the area analyzed by these authors, which does not allow us to appreciate the extremes on the distribution of the bat families in North America or the Neotropics.

Some authors considered that climatic factors have a profound effect on bat distribution and richness (Patten 2004; Stevens 2004; Pereira and Palmeirim 2013; Peixoto et al. 2017) because higher richness accumulates in environments resembling the ancestral niche, thus supporting phylogenetic niche conservatism as the mechanism driving the bat diversity gradient; but because niches are phylogenetically conserved within clades, and clades differ in climatic origin in general, the relationship between climate and species richness of mammalian clades is not positive (Buckley et al. 2010). In our analyses the species richness patterns do not respond to environmental gradients (climate). In addition, vegetation types can be an indicator of the productivity and availability of food in a specific area and the richness patterns of a given group, but in our analyses of the bat richness patterns they also do not respond to vegetation types (Tables 4 and 5). For both climate and vegetation, at the familial level richness is distributed throughout the country, but the greatest richness is concentrated in areas where there is high climatic diversity and the confluence of diverse vegetation types (Figures 3 and 4).

Great differences exist between the richness patterns displayed for the bat families within the biotic provinces proposed for the country (Table 3). Willig et al. (2003) point out that for North American mammals the larger biotic provinces contain more taxa (species, genera and families) than their smaller counterparts, but in our study this is not observed for Mexican bats. These differences are associated with the criteria used for the establishment of the biotic provinces, in which priority is given to ecosystems, their functioning and only the presence or absence of some organisms, rather than put the priorities at the origin, radiation processes, phylogeny and habitats of such organisms that are sharing a certain area. For this reason the biotic provinces cannot explain the richness patterns followed by the Mexican bats either as a whole or the taxonomic level of the family.

For the 97 bat species as a whole, the modelled distributions maps show a greater concentration of species richness in three areas of the country: 1) The area in western Mexico where the biotic provinces of the Trans-Mexican Volcanic Belt and the Mexican Pacific Coast converge. 2) Northeastern Mexico, where the biotic provinces of Tamaulipas, the Sierra Madre Oriental and the Coastal Plains of the Gulf of Mexican unite. 3) The Isthmus of Tehuantepec area, where the provinces of the Sierra Madre del Sur, the Coastal Plains of Gulf of Mexico and the Highlands of Chiapas converge (see Chiroptera in Figure 3). The maps also show that each family has a particular pattern of species richness across the country (Figure 3 ) and the points where it is concentrated are scattered. This suggests that the bat richness concentration in some areas is probably due to the environmental heterogeneity, areas with a complex topography that give rise to a wide diversity of climates and vegetation types that promote the formation of several habitats within a relatively small territorial extension; this is in accord with Willig and Presley (2018) who postulate that the variation in species composition among local assemblages is typically associated with habitat heterogeneity and contributes to the disparity between biodiversity at local and regional scales.

Arita et al. (2014) proposed that bat richness in Mesoamerica is determined at the generic level by the distinct tendencies of diverse clades and is tightly linked with the origin and the processes of diversification at the family level. For instance, the families Vespertilionidae and Natalidae have a North American origin, while the family Molossidae underwent an early diversification in South America. Meanwhile, the diversification processes for Mormoopidae and Phyllostomidae and probably for Emballonuridae were complex. In the maps obtained by us only the richness pattern observed in Vespertilionidae may be viewed as a reflection of the family's origin.

The richness of bats among biotic provinces is very complex to attribute only to the conjugation of some environmental factors and the types of vegetation existing in them. López-González et al. (2012) proposed that the structure of Mexican bat meta-communities is associated with multiple environmental gradients at different spatial scales and that the distribution of bats along environmental gradients is determined by characteristics of the species group and not the defined study areas that arbitrarily confine them. Our results show a similar behavior for concentrated bat richness.

Bat families differ in their richness patterns, so studies of bat biogeography in Mexico may be misleading if they are examined only at the ordinal level; beside this the results of this study also show that the species richness of bats and their relationship with environmental parameters are more complex than previously reported and that the distribution patterns can differ depending on the taxonomic level or the parameters considered. Likewise, the bat richness is similar for the vegetation and climate types; but due to the complex orography of the country representation of these two factors on a map is very complex (Figures 4a, 4b).

Vegetation and climate, either independently or together, do not completely explain the observed richness patterns, thereby demonstrating the need to examine different dimensions of richness as well as the biological richness of bats in megadiverse ecosystems using new approaches that consider phylogenetic aspects and the evolutionary history of each taxon.

Other authors have already mentioned some of the areas in this study with the greatest species richness. For example, Chamela, Jalisco (western Mexico); Los Tuxtlas, 
Veracruz (to the west of the Isthmus of Tehuantepec); and El Triunfo, Chiapas (to the east of the Isthmus of Tehuantepec), are mentioned in the study of Arita and Ortega (1998) as localities with high species richness. In the maps generated in this study, these localities each represent one point within much wider areas of high species richness, wherein the species richness decreases with respect to increasing distance from these points.

Various authors have highlighted the importance of the 'Mexican transition zone', an area where the Nearctic and Neotropical regions converge, for understanding the diversity patterns of mammals (Ortega and Arita 1998; Fa and Morales 1991; Escalante et al. 2005; Morrone and Escalante 2002). The generated maps also demonstrate the importance of this zone for bat species as a whole and particularly for Phyllostomidae. In addition, the maps show the significance of the Río Balsas Basin and the Trans-Mexican Volcanic Belt, especially for the families Mormoopidae and Vespertilionidae.

Our results highlight that for Mexican bats, patterns may be dependent on characteristics of spatial scale and taxonomic hierarchy and also point out the need to consider, beside the origin and diversification process, the potential differences in the macroecology and biogeography among families. Additional analyses that consider the patterns of richness presented in this study and that incorporate at the same time other variables (productivity, environmental structure, and landscape heterogeneity) and processes (phylogenetic and functional diversity) could reveal new information about the factors that influence and shape the distribution of bat species richness, both overall and for distinct clades.

Bats are related to the upkeep of ecosystem services that are very important for the maintenance of humid

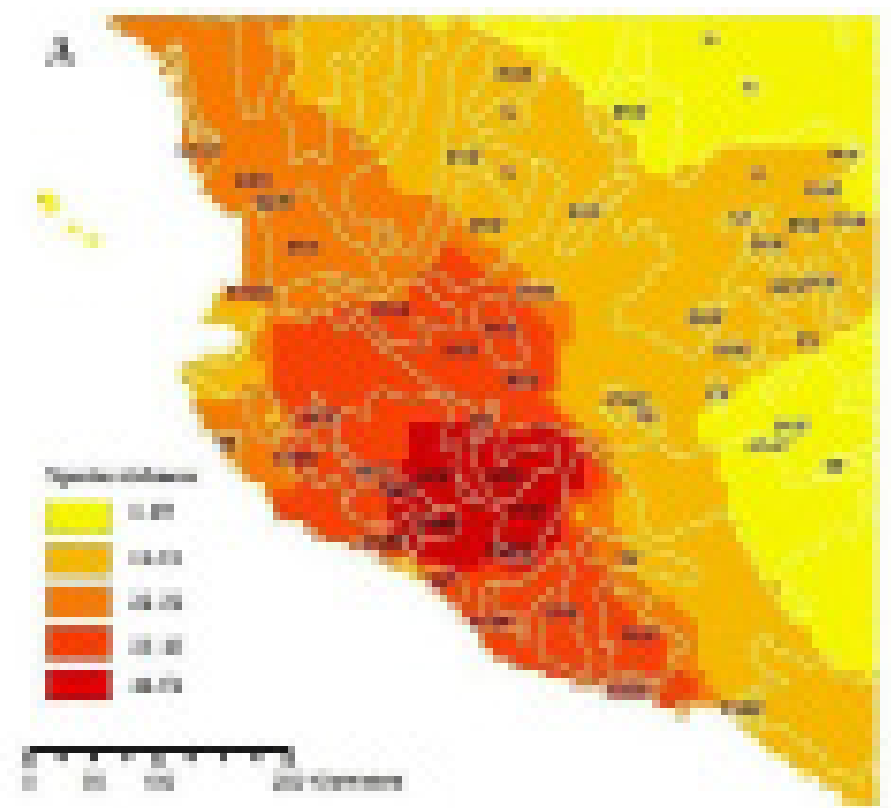

tropical forests, dry forests, cactus plants, xerophilous thickets and cave environments, in which they perform as pollinators, seed dispersers and regulators of insect populations (Kunz et al. 2011). The application of conservation plans for bats will make it possible to preserve these ecoservices and others relevant to human beings, such as the control of various insect pests in plants of agricultural interest (Maine and Boyles 2015), the pollination of plants with commercial interest (Rocha et al 2006; Valenzuela 2011) as well as in the field of human health, because bats are also controllers of insect populations that can be vectors of important diseases such as malaria, dengue, zika and chikungunya, among others (Plowright et al. 2015).

The protection of areas with high concentration of bat richness, especially the rich hotspot diversity areas showed in this paper, should be a priority during the development of conservation strategies. The analysis of geographical concentrations of endemic taxa are frequently used to determine priorities for conservation actions; preserving areas with a broader taxonomic focus, such as the one proposed in this study at the family level, would consider phylogenetic relationships (evolutionary history) among taxa. It may therefore provide a better currency for conservation evaluation than only species richness.

Decision makers should consider the richness patterns presented in this study in order to design appropriate strategies for the conservation of bats in Mexico. Their conservation is especially important considering their high ecological value, furthermore, their richness patterns result from the interaction of multiple variables and processes that affect other faunistic groups in addition to bats.

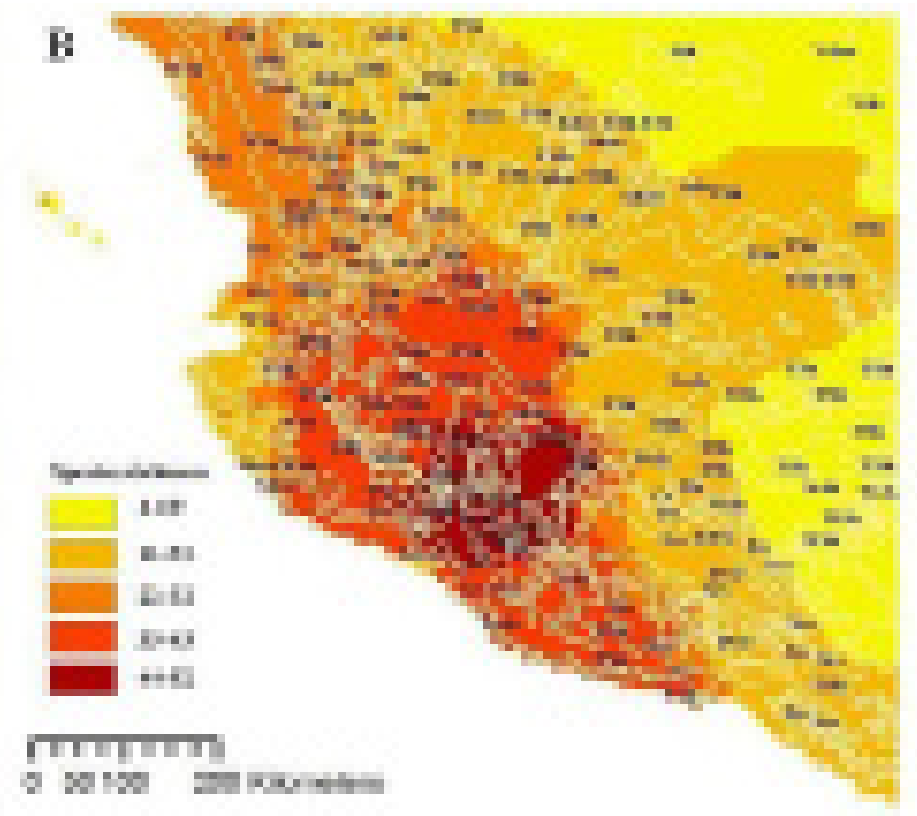

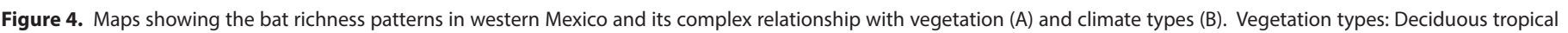

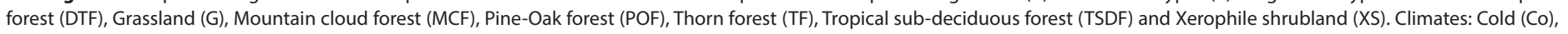

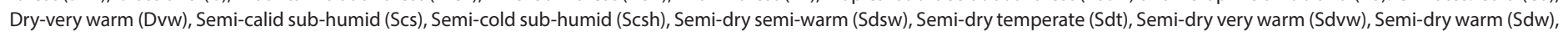

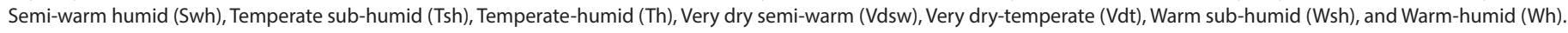


The results presented here enable a general understanding of the species richness patterns of bats and of the areas where this richness is concentrated and its relationship with diverse biogeographic regions and environmental parameters. Even so, these results are not completely satisfactory, due to methodology problems.

Novel techniques for identifying insectivorous bats have been developed (ultrasonic detectors) do not necessarily involve the capture of individuals, so species records can change, causing possible variations in the maps presented here. The utilized scale of $1: 1,000,000$ and the use of a $1^{\circ}$ $\mathrm{X} 1^{\circ}$ grid functioned well for the biogeographical regions (biotic provinces) but not for environmental factors considered (vegetation and climate). Along the country some climates types had a limited or very fragmented geographical distribution with the utilized scale these climates occupied the same cells dominated by other climate types with a wider geographical distribution; therefore, in the analyses, the relationships of the cold, semi-warm humid, semi-dry semi-cold, and temperate-humid climate types with species richness were excluded from the results. This same phenomenon occurs also with vegetation types and for the Mountain cloud forest the analysis either did not generate results. This highlights the need to investigate the interactions with environmental parameters at different scales in order to have a better understanding of the richness patterns in Mexican bats.

\section{Acknowledgements}

We thank the División de Ciencias Biológicas y de la Salud of the Universidad Autónoma Metropolitana-Iztapalapa, the Consejo Nacional de Ciencia y Tecnología (CONACYT projects 128459 and 243138) and the Dirección de Superación Académica; PRODEP UAM-I-CA-89; COFON 14312123) for financing our research on bats in Mexico. In particular, we would like to thank Erik Marquez García for his support in the use of ordinary kriging. This article is part of the doctoral thesis of Kinberly M. Barrios Gómez (CONACYT scholarship number 248832), doctoral student at the División de Ciencias Biológicas y de la Salud of the Universidad Autónoma Metropolitana-Iztapalapa. We appreciate the helpful comments and suggestions made by the associated editor and two anonymous reviewers that improve this work.

\section{Literature cited}

Aguirre, L. F., F. Montaño-Centellas, M. M. Gavilánez, and R. D. Stevens. 2016. Taxonomic and phylogenetic determinants of functional composition of Bolivian bat assemblages. PLoS ONE 11: e0158170. doi:10.1371/journal.pone.0158170. Altringham, J. D. 1997. Bats: Biology and Behaviour. Oxford University Press. New York, United States.

Alvarez-Castañeda, S. T., T. Álvarez, and N. González-Ruiz. 2015. Guía para la identificación de los mamíferos de México en campo y laboratorio. Asociación Mexicana de Mastozoología y Centro de Investigaciones Biológicas del Noreste, México.
Alvarez-Castañeda, S. T., T. Álvarez, and N. González-Ruiz. 2017. Keys for identifying Mexican Mammals in the field and in the laboratory. The Johns Hopkins University Press.

ARITA, H. T., J. VARGAS-BARÓN, AND F. VILlalobos. 2014. Latitudinal gradients of genus richness and endemism and the diversification of New World bats. Ecography 37:1024-1033.

ARITA, H. T. 1993. Riqueza de especies de la mastofauna de México. Pp. 109-128 in Avances en el estudio de los mamíferos de México (Medellín, R. A., and G. Ceballos, eds.). México. Asociación Mexicana de Mastozoología, Ciudad de México, México.

ARITA, H. T. 1997. The non-volant mammal fauna of Mexico: species richness in a megadiverse country. Biodiversity Conservation 6:787-795.

ARITA, H. T., AND J. ORTEGa. 1998. The Middle American bat fauna: conservation in the neotropical-nearctic border. Pp. 295-308 in Bat Biology and Conservation (Kuns, T. H., and P. A. Racey, eds.). Smithsonian Institution Press, Washington, U. S. A.

Arriaga, L., C. Agullar, D. Espinosa, and R. Jiménez. 1997. Regionalización ecológica y biogeográfica de México. Comisión Nacional para el Conocimiento y Uso de la Biodiversidad (CONABIO). Ciudad de México, México.

Bellamy, C., C. Scott, AND J. Altringham. 2013. Multiscale, presenceonly habitat suitability models: fine-resolution maps for eight bat species. Journal of Applied Ecology 50:892-901.

Bergallo, H. G., C. E. Esbérard, M. A. R. Mello, V. Lins, R. Mangolin, G. G. MeLO, AND M. BAPTISTA. 2003. Bat species richness in Atlantic Forest: What is the minimum sampling effort? Biotropica 35:278-288.

Brunet-RossinI, A. K, AND S. N. Austad. 2004. Ageing studies on bats: a review. Biogerontology 5:211-222.

Buckley, L. B., T. J. Davies, D. D. Ackerly, N. J. B. Kraft, S. P. Harrison, B. L. Anacker, H. V. Cornell, E. I. Damschen, J. A. Grytnes, B. A. Hawkins, C. M. McCain, P. R. Stephens, And J. J. Wiens. 2010. Phylogeny, niche conservatism and the latitudinal diversity gradient in mammals. Proceedings of the Royal Society B 277:2131-2138. Ceballos, G., P. Rodriguez, and R. A. Medellín. 1998. Assessing conservation priorities in megadiverse Mexico: mammalian diversity, endemicity, and endangerment. Ecological Applications 8:8-17.

Cisneros, L. M., M. E. Fagan, And M. R. Willig. 2014. Effects of human-modified landscapes on taxonomic, functional and phylogenetic dimensions of bat biodiversity. Diversity and Distributions 21:523-533.

CRIChton, E. G., AND P. H. KrUtzsCh. 2000. Reproductive Biology of Bats. Academic Press, London, England.

Cruz-Cárdenas, G., J. L. Villaseñor, L. López-Mata, and E. Ortiz. 2013. Distribución espacial de la riqueza de especies de plantas vasculares en México. Revista Mexicana de Biodiversidad 84:1189-1199.

Díaz, V. M. A. 2002. Geoestadística aplicada. Instituto de Geofísica, Universidad Nacional Autónoma de México (UNAM). Instituto de Geofísica y Astronomía, CITMA Cuba. Escalante, T., D. Espinosa, and J. J. Morrone. 2002. Patrones de distribución geográfica de los mamíferos terrestres de México. Acta Zoológica Mexicana (n. s.) 87:47-65.

EsCALANTE, T., D. EsPinOSA, AND J. J. MoRrone. 2003. Using parsimony analysis of endemism to analyze the distribution of Mexican land mammals. Southwestern Naturalist 48:563-578. 
Escalante, T., G. RodrígueZ, And J. J. Morrone. 2005. Las provincias biogeográficas del componente mexicano de montaña desde la perspectiva de los mamíferos continentales. Revista Mexicana de Biodiversidad 76:199-205.

Escalante, T., J. J. MorRone, AND G. RodríGUeZ. 2007. La distribución de los mamíferos terrestres y la regionalización biogeográfica natural de México. P.p. 9-17 in Tópicos en Sistemática, Biogeografía, Ecología y Conservación de Mamíferos (Sánchez-Rojas, G., and A. E. Rojas-Martínez, eds.). Universidad Autónoma del Estado de Hidalgo. México. ESRI (Environmental Systems Research Institute). 2006. ArcGis 9.2, Geoestatistical analyst tutorial. New York, U. S. A.

Estrada, A., and R. Coates-Estrada. 2001. Bat species richness in live fences and in corridors of residual rain forest vegetation at Los Tuxtlas, Mexico. Ecography 24:94-102.

Estrada, A., R. Coates-Estrada, And D. MerRitT. 1993. Bat species richness and abundance in tropical rain forest fragments and in agricultural habitats at Los Tuxtlas, Mexico. Ecography 16:309-318.

FA, J. E., and L. M. Morales. 1991. Mammals and protected areas in the Trans-Mexican Neovolcanic Belt. Pp. 199-226 in Latin American mammalogy. History, biodiversity, and conservation (Mares, M. A. and D. J. Schmidly, eds.). The University of Oklahoma Press. Norman, Oklahoma. U. S. A.

Fenton, M. B., And N. B. Simmons. 2015. Bats: A World of Science and Mystery. University of Chicago Press. U. S. A.

FindLEY, J. S. 1993. Bats, a community perspective. Cambridge University Press, Cambridge, England.

Fortin, M. J., T. Keitt, B. A. Maurer, M. L. Taper, D. M. Kaufman, AND T. M. BLACKBURN. 2005. Species' geographic ranges and distributional limits: pattern analysis and statistical issues. Oikos 108:7-17.

Frey-Ehrenbold, A., F. Bontadina, R. Arlettaz, and M. Obrist. 2013. Landscape connectivity, habitat structure and activity of bat guilds in farmland-dominated matrices. Journal of Applied Ecology 50:252-261.

García, E. 1998. Climas (Clasificación de Koppen, modificado por García). Escala 1:1,000,000. Edición 2002. Comisión Nacional para el Conocimiento y Uso de la Biodiversidad (CONABIO). México.

García-Morales, R., E. I. Badano, And C. E. Moreno. 2013. Response of neotropical bat assemblages to human land use. Conservation Biology 27:1-11.

GrimshaW, J. R., AND C. L. HigGins. 2017. Environmental correlates of phylogenetic structure in Mexican bat communities. Journal of Mammalogy 98:1657-1666.

Hall, E. R., and K. R. Kelson. 1959. The mammals of North America. The Ronald Press, New York, U. S. A.

Hansen, A. F. 1997. Cartografía básica para estudiantes y técnicos. Dirección General de Geografía. INEGI. Aguascalientes., México.

Henríquez, C., J. C. Méndez, and R. Masís. 2013. Interpolación de variables de fertilidad de suelo mediante el análisis de Kriging y su validación. Agronomía Costarricense 37:71-82.

HenGL, T. 2009. A practical guide to geostatistical mapping. Office for Official Publications of the European Communities, Luxembourg.

Henry, M., J. F. Cosson, And J. M. Pons. 2010. Modelling multiscale spatial variation in species richness from abundance data in a complex Neotropical bat assemblage. Ecological
Modelling 221:2018-2027.

HorTAL, J., AND J.M. LoBo. 2011. Can species richness patterns be interpolated from a limited number of well-known areas? Mapping diversity using GLM and kriging. Natureza y Conservação-Brazilian Journal of Nature Conservation 9:200-207.

KAUfMAN, D. M. 1995. Diversity of New World mammals: universality of the latitudinal gradients of species and bauplans. Journal of Mammalogy 76:322-334.

Kunz, T. H., E., Braun de Torrez, D. M., Bauer, T. A., Lobova, and T. H. Fleming. 2011. Ecosystem services provided by bats. Annals of the New York Academy of Sciences 12:1-38.

Kunz, T. H., AND M. B. Fenton. 2003. Bat Ecology. University of Chicago Press, United States.

López-González, C., S. J. Presley, A. Lozano, R. D. Stevens, and C. L. HIGGINS. 2012. Metacommunity analysis of Mexican bats: environmentally mediated structure in an area of high geographic and environmental complexity. Journal of Biogeography 39:177-192.

López-González, C., S. J. Presley, A. Lozano, R. D. Stevens, and C. L. HIGGINS. 2015. Ecological biogeography of Mexican bats: the relative contributions of habitat heterogeneity, beta diversity, and environmental gradients to species richness and composition patterns. Ecography 38:261-272.

MAINE, J. J., AND J. G. BoYLES. 2015. Bats initiate vital agroecological interactions in corn. Proceedings of the National Academy of sciences 112:12438-12443.

McCAIn, C. M. 2007. Could temperature and water availability drive elevational species richness patterns? A global case study for bats. Global Ecology and Biogeography 16:1-13.

McCoY, E. D., AND E. F. CONNOR. 1980. Latitudinal gradients in the species diversity of North American mammals. Evolution 34:193-203.

Medellín, R. A., H. T. Arita, and O. Sánchez. 2008. Identificación de los murciélagos de México: clave de campo. Instituto de Ecología, UNAM. México.

Mehr, M., R. Brandl, T. Hothorn, F. Dziock, B. Förster, and J. Müller. 2011. Land use is more important than climate for species richness and composition of bat assemblages on a regional scale. Mammalian Biology 76:451-460.

Melo, A. S., M. V. Cianciaruso, and M. Almeida-Neto. 2014. treeNODF: nestedness to phylogenetic, functional and other tree-based diversity metrics. Methods in Ecology and Evolution 5:563-572.

Meyer, C. F., L. Aguilar, L. F. Aguirre, J. Baumgarten, F. M. Clarke, J. F. Cosson, AND M. Henry. 2011. Accounting for detectability improves estimates of species richness in tropical bat surveys. Journal of Applied Ecology 48:777-787.

Morrone, J. J. 2005. Hacia una síntesis biogeográfica de México. Revista Mexicana de Biodiversidad 76:207-252.

Morrone, J. J., AND T. Escalante. 2002. Parsimony analysis of endemicity (PAE) of Mexican terrestrial mammals at different area units: when size matters. Journal of Biogeography 29:1095-1104.

NeuWeIler, G. 2000. The Biology of Bats. Oxford University Press. U.S. A.

Ortega, J., and H. Arita. 1998. Neotropical-Nearctic limits in Middle America as determined by distributions of bats. Journal of Mammalogy 79:772-783. 
Patten, M. A. 2004. Correlates of species richness in North American bat families. Journal of Biogeography 31:975-985.

Peixoto, F. P., F. Villalobos, and M. V. Cianciaruso. 2017. Phylogenetic conservatism of climatic niche in bats. Global Ecology and Biogeography 2:1055-1065.

Pereira, M. J. R., AND J. M. Palmeirim. 2013. Latitudinal diversity gradients in New World bats: are they a consequence of niche conservatism? PLoS One, 8(7):e69245.

Phillips, S. J., R. P. Anderson, and R. E. Schapire. 2006. Maximum entropy modeling of species geographic distributions. Ecological Modelling 190:231-259.

Plowright, R. K., P. Eby, P. J. Hudson, I. L. Smith, D. Westcott, W. L., Bryden, D. Middleton, P. A. Reid, R. A. McFarlane, G. Martin, G. M. Tabor, L. F. Skerratt, D. L. Anderson, G. Crameri, D. Quammen, D. Jordan, P. Freeman, L. F.WANG, J. H. Epstein, G. A. Marsh, N. Y. Kung, AND H. McCallum. 2015. Ecological dynamics of emerging bat virus spillover. Proceedings of the Royal Society B 282:2014-2124.

QGIS Development Team. 2012. QGIS Geographic Information System. Open Source Geospatial Foundation. URL www. qgis.org.

Ramírez-Pulido, J., and A. Castro-Campillo. 1990. Provincias mastofaunísticas. Carta IV.8.8a, escala 1:4,000,000, Atlas Nacional de México. Volumen II, México: Instituto de Geografía, UNAM. México.

Ramírez-Pulido, J., and A. Castro-Campillo. 1993. Diversidad mastozoológica en México. Revista de la Sociedad Mexicana de Historia Natural 44:413-427.

Rocha, M., S. V., Good-Ávila, F., Molina-Freaner, H. T., Arita, A., Castillo, A., García-Mendoza, A., Silva-Montellano, B. S., Gaut, V., Souza, And L. E. Eguiarte. 2006. Pollination biology and adaptive radiation of Agavaceae, with special emphasis on the genus Agave. Aliso: A Journal of Systematic and Evolutionary Botany 22:329-344.

Rondinini, C., K. A. Wilson, L. Boitani, H. Grantham, and H. P. Possingham. 2006. Tradeoffs of different types of species occurrence data for use in systematic conservation planning. Ecology letters 9:1136-1145.

Roncancio, N., and J. Estévez. 2007. Evaluation of the bat assemblage in areas subjected to a natural regeneration and to a restoration by means of alder plantations. Boletín Científico. Centro de Museos. Museo de Historia Natural 11:131-143.

RzEDowsKI, J. 1990. Vegetación Potencial 1:4000000, IV.8.2. Atlas Nacional de México. Vol. II. Instituto de Geografía, UNAM. México.

Sarukhán, J., T. Urquiza-HaAs, P. Koleff, J. Carabias, R. Dirzo, E. Ezcurra, S. Cerdeira-Estrada, and J. Soberón. 2014. Strategic actions to value, conserve, and restore the natural capital of megadiversity countries: the case of Mexico. BioScience 65:164-173.

Segura-Trujillo, C. A., and S. Navarro-Pérez. 2010. Escenario y problemática de conservación de los murciélagos (Chiroptera) cavernícolas del Complejo Volcánico de Colima, Jalisco-Colima. Therya 1:189-206.

Scheiner, S. M., E. Kosman, S. J. Presley, and M. R. Willig. 2016. Decomposing functional diversity. Methods in Ecology and Evolution 8:809-820.

Schoeman, M. C., F. D. P. Cotterill, P.J.Taylor, and A.Monadjem. 2013. Using potential distributions to explore environmental correlates of bat species richness in southern Africa: Effects of model selection and taxonomy. Current Zoology 59:279-293.

Simmons, N. B. 2005. Order Chiroptera. Pp. 312-529 in Mammal Species of the World: A Taxonomic and Geographic Reference (Wilson, D. E., and D.M. Reeder, eds.). Johns Hopkins University Press, Baltimore, Maryland U. S. A.

Skalak, S. L., R. E. Sherwin, and R. M. Brigham. 2012. Sampling period, size and influence measures of bat species richness from acoustic surveys. Methods in Ecology and Evolution 3:490-502.

SORIANO, P. J. 2000. Functional structure of bat communities in tropical rainforests and Andean cloud forests. Ecotropicos 13:1-20.

SteVens, R. D. 2004. Untangling latitudinal richness gradients at higher taxonomic levels: familial perspectives on the diversity of New World bat communities. Journal of Biogeography 31:665-674.

Stevens, R.D., S. B. Cox, R. E. Strauss, and M. R. Willig. 2003. Patterns of functional diversity across an extensive environmental gradient: vertebrate consumers, hidden treatments and latitudinal trends. Ecology Letters 6:1099-1108.

Stevens, R. D., And M. R. Willig. 2002. Geographical ecology at the community level: perspectives on the diversity of new world bats. Ecology 83:545-560.

Tapia-Silva, F. O., O. E. Hernández-Cervantes, M. I. Vilchis-Alfaro, A. Sentíes, And K. M. DreCKMAnn. 2015. Mapping of algae richness using spatial data interpolation. International Journal of Remote Sensing of Environment 40:1005-1008.

Tello, J. S., And R. D. Stevens. 2010. Multiple environmental determinants of regional species richness and effects of geographic range size. Ecography 33:796-808.

Tittensor, D. P., C. Mora, W. Jetz, H. K. Lotze, D. Ricard, E. V. Berghe, AND B. Worm. 2010. Global patterns and predictors of marine biodiversity across taxa. Nature 466:1098-1101.

Valenzuela, A. N. A. 2011. A new agenda for blue agave landraces: food, energy and tequila. Gcb Bioenergy 3:15-24.

Wang, H. G., R. D. Owen, C. SáncheZ-HernándeZ, and M. L. Romero-Almaraz. 2003. Ecological characterization of bat species distributions in Michoacán, México, using a geographic information system. Global Ecology and Biogeography 12:65-85.

WILLIG, M. R., AND S. K. Lyons. 1998. An analytical model of latitudinal gradients of species richness with an empirical test for marsupials and bats in the New World. Oikos 81: 93-98.

Willig, M. R., D. M. Kaufman, And R. D. Stevens. 2003. Latitudinal gradients of biodiversity: pattern, process, scale, and synthesis. Annual Review of Ecology, Evolution, and Systematics 34:273-309.

Willig, M. R., ANd S. J. Presley. 2018. Latitudinal gradients of biodiversity: theory and empirical patterns. Pp. 13-19 in The encyclopedia of the anthropocene (DellaSala, D. A., and M. I. Goldstein, eds.), vol. 3, Oxford, Elsevier, U. S. A.

WILSON, III, J. W. 1974. Analytical zoogeography of North American mammals. Evolution 28:124-140.

Associated editor: Robert Owen

Submitted: April 16, 2018; Reviewed: July 2, 2018;

Accepted:December 24, 2018; Published on line: January 15, 2019. 
24 THERYA Vol. 10 (1): 11-23 